\title{
Cell-specific Regulation of Type II Phospholipase A2 Expression in Rat Mesangial Cells
}

\author{
M. Konieczkowski and J. R. Sedor * \\ Departments of Medicine and Physiology and * Biophysics, School of Medicine, Case Western Reserve University \\ and Divisions of Nephrology, MetroHealth Medical Center and University Hospitals, Cleveland, Ohio 44109
}

\begin{abstract}
IL-1 stimulates mesangial cells to synthesize specific proteins, including a non-pancreatic (Type II) phospholipase $\mathbf{A}_{2}$ $\left(\mathrm{PLA}_{2}\right)$. We have studied the regulation of PLA $\mathrm{A}_{2}$ by proinflammatory mediators, implicated in the pathogenesis of glomerulonephritis, and have assessed whether the activation of second messenger systems modulates or mimics PLA $\mathbf{A}_{2}$ gene expression by cytokines. IL-1 $\alpha$ and $\beta$, TNF $\alpha$, and LPS, but not serum, IL-2, or PDGF, potently induce PLA 2 mRA, and enzyme expression. IL-1-stimulated mesangial cells express a $1.0 \mathrm{kB}$ $P_{2} A_{2}$ mRA transcript that is induced in a dose- and time-dependent manner. IL-1-stimulated increases in steady-state PLA $_{2}$ mRNA abundance result from a moderate increase in $\mathrm{PLA}_{2}$ transcription rate that is amplified by the prolonged persistence of the transcript. Forskolin and dibutyryl cAMP potentiate IL-1-induced PLA mRNA and enzyme expression, but have no effect in the absence of cytokine. 12-tetradecanoyl phorbol 13-acetate, sn-1, 2-dioctanoyl glycerol or 1-oleoyl-2acetyl-sn-glycerol fail to induce $\mathrm{PLA}_{2}$ expression or to alter the effect of IL-1 when coincubated with the cytokine. In contrast, serum deprivation for $24 \mathrm{~h}$ specifically enhances IL-1-stimulated PLA $\mathbf{A}_{2}$. Genistein potentiates PLA mRNA expression in cells exposed to both IL-1 and serum. The inhibitory effect of serum on IL-1-induced PLA $A_{2}$ mRNA abundance is reproduced by PDGF but not dexamethasone. These data demonstrate that the signaling pathways directly engaged by IL-1 to induce PLA $\mathbf{A}_{2}$ expression in mesangial cells interact with several second messenger systems in a cell-specific manner. We speculate that IL-1 induces specialized changes in mesangial cell structure and function through direct activation of a transcription factor(s), that result in induction of a specific gene set. ( $J$. Clin. Invest. 1993.92:2524-2532.) Key words: cell phenotype • cell differentiation - interleukin-1 - glomerulonephritis • cytokine
\end{abstract}

\section{Introduction}

The mesangial cell occupies a central anatomical position within the glomerulus $(1,2)$. Historically this cell has been regarded as unifunctional, only being important in the regula-

This work was presented in part at the annual meeting of the American Society of Nephrology, 2-5 December 1990, Washington, DC.

Address correspondence to Dr. John R. Sedor, Division of Nephrology, MetroHealth Medical Center, 2500 MetroHealth Drive, Office R-338, Cleveland, OH 44109-1998. 1993

Received for publication 23 June 1992 and in revised form 16 July

J. Clin. Invest

(c) The American Society for Clinical Investigation, Inc. 0021-9738/93/011/2524/09 \$2.00

Volume 92, November 1993, 2524-2532 tion of glomerular filtration rate. However, in vitro and in vivo evidence suggests that the mesangial cell both produces and responds to biological modifiers and participates in the destructive and restorative processes that follow the initiation of glomerular injury $(1,2)$. Intraglomerular expression of the cytokines, IL- 1 and TNF $\alpha^{1}$ has been demonstrated in both human and experimental glomerulonephritis $(3,4)$. IL-1 and TNF activate the mesangial cell in culture to express new structural and functional characteristics in part by inducing expression of specific genes $(3,4)$. IL- $1 \alpha$, IL- $1 \beta$, and TNF stimulate release of the neutrophil chemotactic intercrine, IL-8 (5-7), and IL-6 $(6,7)$ and regulate expression of genes controlling extracellular matrix synthesis and turnover $(3,4,8)$. We have demonstrated in rat mesangial cells that IL- $1 \alpha$ directly stimulates prostaglandin synthesis by increasing phospholipase $\mathrm{A}_{2}\left(\mathrm{PLA}_{2}\right)^{1}$ activity through synthesis of a nonpancreatic (Type II) $\mathrm{PLA}_{2}$ (9). The increases in $\mathrm{PLA}_{2}$ activity and $\mathrm{PLA}_{2}$ mRNA expression are coordinate and follow the same time course as cytokine-stimulated $\mathrm{PGE}_{2}$ synthesis.

As a result of these and other studies, many investigators have hypothesized that TNF- and IL-1-stimulated mesangial cells express an altered phenotype that contributes to glomerular injury. The intracellular events that mediate the cytokineinduced transition of mesangial function are poorly understood. This process involves induction of a specific gene set by a network of short-term signals generated by interaction of the cytokine with the binding domain of its receptor. The cytosolic signals generated by IL- 1 and TNF in the mesangial cell have been fairly well defined. We and others have shown that IL-1 $\alpha$ rapidly stimulates 1, 2-diacylglycerol and phosphatidic acid formation $(10,11)$ but does not induce rapid changes in cystolic $\mathrm{Ca}^{2+}$ or $\mathrm{pH}_{\mathrm{i}}(10)$. Both IL-1 and TNF cause phosphorylation of mesangial cell proteins, but neither cytokine increases the phosphorylation of the putative $80 \mathrm{kD}$ substrate of protein kinase $\mathrm{C}(3,12)$. Pfeilschifter shows no increase in cAMP accumulation in response to IL-1 (13), and TNF and IL-1 only stimulate cGMP formation after 4 to $6 \mathrm{~h}(14,15)$.

We have used the induction of PLA $_{2}$ mRNA expression by IL-1 as a model system to define whether these early signals are converted to long-term changes in cell phenotype through induction of specific genes. Our studies suggest that the signalling pathways directly engaged by IL-1 in the mesangial cells interact with several second messenger systems in a cell-specific manner.

\section{Methods}

Materials. Recombinant human IL-1 $\alpha$ (rIL-1), and TNF were kindly provided by Drs. Peter Lomedico (Hoffmann-LaRoche, Nutley, NJ)

1. Abbreviations used in this paper: DiOG, sn-1, 2-dioctanoylglycerol; OAG, 1-oleoyl-2-acetyl-sn-glycerol; PA, phosphatidic acid; PLA, phospholipase $\mathrm{A}_{2}$; rIL-1, recombinant human IL-1 $\alpha$; TPA, tetradecanoyl phorbol 13-acetate. 
and Leo Linn (Cetus Corporation, Emeryville, CA). Specific activities and endotoxin contents have previously been reported $(9,10,16)$. Recombinant human interleukin- $1 \beta\left(2 \times 10^{7} \mathrm{U} / \mathrm{mg}\right)$ was a gift from Dr. Nigel Staite (UpJohn, Kalamazoo, MI), and endotoxin concentration determined by limulus lysate assay was $1.8 \mathrm{ng} / \mathrm{mg}$ protein. Stock cytokines were diluted 1:50,000 before use with pyrogen-free saline containing $2 \mathrm{mg} / \mathrm{ml}$ lipopolysaccharide-free BSA (Calbiochem-Novabiochem Corp., San Diego, CA ). Recombinant human platelet derived growth factor (PDGF, BB homodimer) was obtained from Boehringer Mannheim Biochemicals, Indianapolis, IN. Tetradecanoyl phorbol 13-acetate (TPA), forskolin, genistein, 1-oleoyl-2-acetyl-sn-glycerol $(\mathrm{OAG})$ and $s n$-1, 2-dioctanoylglycerol (diOG) were from CalbiochemNovabiochem Corp. LPS, dibutyryl cAMP and arachidonic acid were supplied by Sigma Chemical Co. (St. Louis, MO). L- $\alpha-1$ palmitoyl, 2-arachidonyl[arachidonyl-1- ${ }^{14} \mathrm{C}$ ]-phosphatidylethanolamine $(60 \mathrm{mCi} / \mathrm{mmol})$, and uridine $5^{\prime}$-triphosphate, $\left[\alpha{ }^{32} \mathrm{P}\right](800 \mathrm{Ci} /$ $\mathrm{mmol}$ ) were purchased from DuPont-New England Nuclear (Boston, MA). Phosphatidic acid, derived from lecithin, was purchased from Avanti Polar Lipids, Inc. (Alabaster, AL). Silica gel 60 thin layer chromatography plates $(250 \mu \mathrm{m}$ thickness) were from E. M. Science (Gibbstown, $\mathrm{NJ}$ ).

Cell culture. Well characterized mesangial cells were grown from collagenase-treated rat glomeruli as previously described $(9,10,16$, 17). Experiments were performed on near confluent cells in passages three to eight. For most studies, cells were incubated in $12.5 \mathrm{mM}$ Hepes buffered RPMI 1640 media containing 5\% FBS (Hyclone Laboratories, Logan, UT). In some experiments, cells were incubated in media lacking FBS (designated 0\% FBS) which contained 0.05\% BSA (Sigma Chemical Co.) or $0.1 \%$ pyrogen-free human serum albumin (Armour Pharmaceutical, Kakakee, IL). In other experiments cells were serumrestricted for $3 \mathrm{~d}$ in RPMI 1640 (M.A. Bioproducts, Walkerville, MD) containing $0.5 \% \mathrm{FBS}$, washed and exposed to PDGF or vehicle.

$P L A_{2}$ activity and $m R N A$ levels. PLA ${ }_{2}$ activity was assayed in acid extracts of vehicle- and cytokine-treated mesangial cells exactly as we have published (9). Briefly, mesangial cells cultured in $75 \mathrm{~cm}^{2}$ flasks were scrapped and homogenized in $0.18 \mathrm{~N} \mathrm{H}_{2} \mathrm{SO}_{4}$ and $1 \mathrm{M} \mathrm{NaCl}$, and the cleared supernatants were dialyzed overnight against $10 \mathrm{mM}$ sodium acetate, $\mathrm{pH}$ 4.4. In some experiments, medium (0\% FBS) was removed and centrifuged briefly at $12,000 \mathrm{~g}$ to remove cellular debris. The extracts and media were stored at $-70^{\circ} \mathrm{C}$ until assay. PLA $_{2}$ activity was assayed in vehicle and rIL-1-treated mesangial cell homogenates $\left(15-30 \mu \mathrm{g}\right.$ protein) and media $(50 \mu \mathrm{l})$ using exogenous $\left[{ }^{14} \mathrm{C}\right]-$ arachidonyl-phosphatidylethanolamine (final concentration, $16 \mu \mathrm{M}$ ) as substrate in the presence of $100 \mathrm{mM}$ Tris $\mathrm{HCl}, \mathrm{pH} 8.5$, and $2.5 \mathrm{mM}$ $\mathrm{CaCl}_{2}$ for $60 \mathrm{~min}$ at $37^{\circ} \mathrm{C}$. Hydrolyzed arachidonic acid was separated from the phospholipid substrate using silica gel thin layer chromatography. The characteristics of $\mathrm{PLA}_{2}$ activity released into the medium are identical to those we have reported for acid-extracted activity (9). Released $P_{L A}$ activity is calcium-dependent ( $99 \%$ reduction by inclusion of $10 \mathrm{mM}$ EGTA in the assay buffer), is inhibited by greater than $85 \%$ by $100 \mathrm{mM} p$-bromophenacyl bromide and represents more than $90 \%$ of the combined acid extractable and secreted PLA $\mathrm{P}_{2}$ activity. Results presented in the figures are shown as the mean \pm SEM value of duplicate determinations from the indicated number of experiments.

Northern analysis of total cellular RNA ( $25 \mu \mathrm{g})$ from vehicle- and rlL-1 stimulated cells was used to size the $\mathrm{PLA}_{2}$ as previously described $(5,9,17)$. Total mesangial cell RNA was extracted using $4 \mathrm{M}$ guanidine isothiocyanate and purified by ultracentrifugation through a cesium chloride cushion. Rat spleen RNA was concurrently analyzed as a positive control. The filters were hybridized at $42^{\circ} \mathrm{C}$ overnight with a full length $\mathrm{PLA}_{2}$ cDNA probe $(2 \mathrm{ng} / \mathrm{ml}$, provided by Dr. Hiroshi Teraoka, Shionogi and Co, Ltd, Osaka, Japan) labeled by nick translation. The membranes were subsequently washed for $30 \mathrm{~min}$ at room temperature with $2 \times$ SSPE $(1 \times$ SSPE: $180 \mathrm{mM} \mathrm{NaCl}, 10 \mathrm{mM} \mathrm{Na}$ $\mathrm{HPO}_{4} \cdot 7 \mathrm{H}_{2} \mathrm{O}$, and $1 \mathrm{mM}$ EDTA), for $30 \mathrm{~min}$ with $2 \times \mathrm{SSPE}, 2 \% \mathrm{SDS}$ at $50^{\circ} \mathrm{C}$, and for $15 \mathrm{~min}$ with $0.1 \times \mathrm{SSPE}, 1 \% \mathrm{SDS}$ at $52^{\circ} \mathrm{C}$. Autoradiograms were obtained by exposing the blots to Kodak XAR-5 film overnight. Transcript size $(\mathrm{kb})$ was derived from an mRNA ladder of known fragment sizes ( Bethesda Research Laboratories, Gaithersburg, $\mathrm{MD})$. The filters were stripped and rehybridized with a ${ }^{32} \mathrm{P}$-labeled chicken $\alpha$-tubulin cDNA probe. IL- 6 mRNA expression was also assayed using the hybridization conditions described above. A ${ }^{32} \mathrm{P}$-labeled 650 bp cDNA fragment from murine IL-6 (gift from Dr. Steven Clark, Genetics Institute, Cambridge, MA) was used as a probe in some studies.

PLA $_{2}$ mRNA abundance was assessed by RNA-RNA solution hybridization as we have previously described in detail (9). Briefly, T7 RNA polymerase was used to synthesize a [ $\left.{ }^{32} \mathrm{P}\right] \mathrm{cRNA}$ probe using a Pvu II-linearized DNA template that contained a cDNA sequence (bp 381-758) for rat splenic, nonpancreatic (Type II) PLA 2 . A heterogenous nucleotide residue found in position 461 of the mature $\mathrm{PLA}_{2}$ RNA transcript produces protected transcripts of both 377 nucleotide and 297 nucleotide (9). For this study, we have constructed, by standard methodologies, an additional DNA template that contains bp 666-759 of the PLA ${ }_{2}$ cDNA. T7 RNA polymerase was used to synthesize a $340 \mathrm{nt}^{32} \mathrm{P}$-labeled probe from this template, which, when hybridized to total cellular RNA, protected a $93 \mathrm{nt}$ transcript. Total mesangial cell RNA and the indicated probes were hybridized at $49^{\circ} \mathrm{C}$ overnight. Following hybridization, unprotected single stranded RNA was digested using RNAse A $(50 \mu \mathrm{g} / \mathrm{ml})$ and T1 $(2 \mu \mathrm{g} / \mathrm{ml})$ for $30 \mathrm{~min}$ at $30^{\circ} \mathrm{C}$ for the first $\left[{ }^{32} \mathrm{P}\right] \mathrm{PLA}_{2}$ probe described and for $25 \mathrm{~min}$ at $22^{\circ} \mathrm{C}$ for the second. $\left.{ }^{32} \mathrm{P}\right]$ RNA-RNA hybrids were analyzed on $5 \%$ or $8 \%$ denaturing polyacrylamide gels and detected by autoradiography (exposures 1-3 d). Transcript abundance was quantitated by densitometry and corrected for background (yeast RNA). Differences between mean PLA $\mathrm{P}_{2}$ mRNA expression were analyzed for statistical signifcance using Student's $t$ test. In some experiments, a ${ }^{32}$ P-labeled RNA probe for human $\alpha$-tubulin (provided by Dr. D. Goldthwait, Department of Biochemistry, Case Western Reserve University, Cleveland, $\mathrm{OH}$ ) was included in the hybridization reactions to assess sample loading and specificity of changes in PLA $\mathrm{A}_{2}$ mRNA expression. A $389 \mathrm{nt}$ ${ }^{32} \mathrm{P}$-labeled transcript was synthesized from a cDNA template that contained a $135 \mathrm{nt}$ sequence of a human $\alpha$-tubulin (1-135 bp). Rat and human $\alpha$-tubulin mRNA are homologous only in their coding region, resulting in a $67 \mathrm{nt}$ protected fragment. Autoradiograms representative of two to four separate experiments are shown.

Nuclear run-off transcription assay. The procedure for in vitro labeling of nuclear RNA was taken from published methods (18) and modified as indicated. Confluent mesangial cells $\left(1.5 \times 10^{7}\right.$ cells/condition $)$ were incubated in $0 \%$ FBS without or with rIL-1 $(10 \mathrm{ng} / \mathrm{ml})$ for $15 \mathrm{~h}$. Nuclei were isolated by lysis in $0.5 \%$ NP-40 using two cycles of dounce homogenization and resuspended in $200 \mu$ l of nuclear freezing buffer (40\% glycerol, $50 \mathrm{mM}$ Tris $\mathrm{HCl}, \mathrm{pH} 8.3,5 \mathrm{mM} \mathrm{MgCl}_{2}$, and $0.1 \mathrm{mM}$ EDTA). The transcription assays were initiated by adding $100 \mu \mathrm{l}$ of $3 \mathrm{X}$ transcription buffer ( $15 \mathrm{mM}$ Tris $\mathrm{HCl}, \mathrm{pH} 8.0,15 \mathrm{mM} \mathrm{MgCl}_{2}, 360$ $\mathrm{mM} \mathrm{KCl}, 7.5 \mathrm{mM}$ DTT, $1.5 \mathrm{mM}$ each of ATP, CTP, GTP, and $0.2 \mu \mathrm{M}$ UTP along with $300 \mu \mathrm{Ci}$ of $\left[{ }^{32} \mathrm{P}\right] \mathrm{UTP}$ [3,000 Ci/mmol; Dupont$\mathrm{NEN}]$ ) to the freshly isolated nuclei. In some cases, the nuclear preparations were preincubated with $\alpha$-amanitin $(1 \mu \mathrm{g} / \mathrm{ml})$ for $10 \mathrm{~min}$ before the start of the transcription assay. After $60 \mathrm{~min}$ at $28^{\circ} \mathrm{C}$, the reaction was terminated by the addition of $100 \mathrm{U}$ of DNase I in $300 \mathrm{mM} \mathrm{NaCl}$, $30 \mathrm{mM} \mathrm{MgCl}_{2}, 1.2 \mathrm{mM} \mathrm{CaCl}_{2}$, and $6.0 \mathrm{mM}$ Tris, $\mathrm{pH}$ 7.4. This suspension was treated subsequently for $30 \mathrm{~min}$ at $37^{\circ} \mathrm{C}$ with proteinase $\mathrm{K}$ $(200 \mu \mathrm{g})$ in $1 \%$ SDS, $5 \mathrm{mM}$ EDTA, and $10 \mathrm{mM}$ Tris, pH 7.4, $(1 \times$ $\mathrm{SET}$ ), extracted with phenol/chloroform/isoamyl alcohol and precipitated overnight at $20^{\circ} \mathrm{C}$ with isopropanol. The precipitate was resuspended in $50 \mu$ l of $1 \times$ SET and centrifuged through a G-25 Sephadex spin column (Quick Spin; Boehringer Mannheim Biochemicals). The purified RNA was subjected to limited base hydrolysis in $0.2 \mathrm{M} \mathrm{NaOH}$ for $7 \mathrm{~min}$ at $4^{\circ} \mathrm{C}$, neutralized with $0.48 \mathrm{M}$ Hepes (free acid), and reprecipitated. Greater than $90 \%$ of the $\left[{ }^{32} \mathrm{P}\right] \mathrm{cpm}$ were precipitated with $10 \%$ trichloroacetic acid. The resulting pellet was resuspended in $10 \mathrm{mM}$ N-tris [hydroxymethyl] methyl-2-aminoethane sulfonic acid (TES), pH 7.4, $10 \mathrm{~mm}$ EDTA, $0.2 \%$ SDS, and $0.3 \mathrm{M} \mathrm{NaCl}$ (TES/ $\mathrm{NaCl})$. Equivalent radioactive RNA $\left(5 \times 10^{6} \mathrm{cpm}\right)$ in $1 \mathrm{ml}$ of TES/ $\mathrm{NaCl}$ were hybridized for $72 \mathrm{~h}$ at $65^{\circ} \mathrm{C}$ with the indicated linearized 
plasmid DNAs ( $7.5 \mu \mathrm{g}$ ) bound to nitrocellulose filters. The plasmids used in these experiments were PLA $_{2}$ (a full-length Type II PLA cDNA cloned into pGEM3Z), IL-6 (a 601 bp murine cDNA probe cloned into pXM, a gift of Genetics Institute), pRGAPDH-1 (a $1.3 \mathrm{~kb}$ rat glyceraldehyde-3-phosphate dehydrogenase [GAPDH]cDNA cloned into pBR322), and a control plasmid, pBR322. After hybridization, the filters were washed twice in $2 \times$ SSC at room temperature, 3 times in $2 \times \mathrm{SSC}$ at $65^{\circ} \mathrm{C}$ for $30 \mathrm{~min}$, and then incubated with RNase $\mathrm{A}$ $(10 \mu \mathrm{g} / \mathrm{ml})$ at $37^{\circ} \mathrm{C}$ for $30 \mathrm{~min}$. The filters were washed subsequently in $2 \times \mathrm{SSC} / 0.2 \% \mathrm{SDS}$ at $65^{\circ} \mathrm{C}$ for $30 \mathrm{~min}$, rinsed in $2 \times \mathrm{SSC}$, and exposed for autoradiography. Hybridized nuclear $\left[{ }^{32} \mathrm{P}\right] \mathrm{PLA}_{2}$ and $\left[{ }^{32} \mathrm{P}\right]-$ GAPDH abundance transcript was quantitated using a scanning densitometer (Scan Maker, Microtek, Torrance, CA) and appropriate software (Adobe Photshop, Adobe Systems, Mountain View, CA; and Scan Analysis Biosoft, Cambridge, UK) and corrected for backgrounds (counts hybridized to pBR322 or $\alpha$-amanitin-insensitive counts hybridized to plasmid). PLA $A_{2}$ transcription rates were determined from the

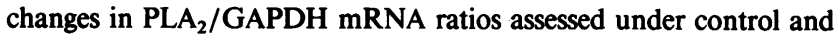
IL-1-stimulated conditions.

Message stability assay. Mesangial cells were incubated in 5\% FBS media in the presence of rIL-1 $(10 \mathrm{ng} / \mathrm{ml})$ for $24 \mathrm{~h}$, the time of maximal PLA ${ }_{2}$ mRNA induction by IL-1. Actinomycin D $(5 \mu \mathrm{g} / \mathrm{ml})$ was added to some dishes. Since certain mRNAs are stabilized in the presence of IL-1 (19), media containing IL-1 was removed from some cells before the addition of actinomycin $D$. Cells from each experimental protocol were harvested at the indicated times. Total cellular RNA was prepared and analyzed by Northern blotting for PLA $\mathrm{P}_{2}$ mRNA expression. In some experiments, mesangial cells were stimulated with IL- 1 in the absence of serum. However the presence or absence of serum had

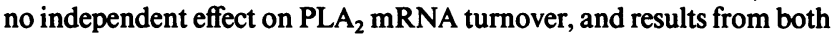
experimental conditions have been pooled. In some experiments, the blots were rehybridized with the $\alpha$-tubulin probe, and $T_{1 / 2}$ for tubulin mRNA was determined from a first-order decay plot.

\section{Results}

Proinflammatory cytokines induce the expression of a nonpancreatic PLA $A_{2}$ in mesangial cells. We first characterized the induction of PLA ${ }_{2}$ mRNA and enzyme expression by rIL-1. As shown in Fig. 1, mesangial cells incubated in 5\% FBS in the presence of $\mathrm{rIL}-1(10 \mathrm{ng} / \mathrm{ml})$ express a single $1.0 \mathrm{~kb}$ PLA $_{2}$
mRNA transcript (Fig. $1 A$ ). The PLA 2 transcript was detectable by $6 \mathrm{~h}$ of incubation with rIL-1. Transcript abundance increased with time and reached a plateau after $16 \mathrm{~h}$ (Fig. $1 \mathrm{~B}$ ). In 24 hour incubations, rIL-1 induced a dose-dependent, coordinate increase in $\mathrm{PLA}_{2}$ mRNA and activity (Fig. $1 C$, Table I). The threshold concentration for rIL-1 stimulated PLA $\mathrm{P}_{2}$ expression was $1.0 \mathrm{ng} / \mathrm{ml}$. The rIL-1-induced increase steady state $\mathrm{PLA}_{2} \mathrm{mRNA}$ was not affected by coincubation with cycloheximide for two (not shown), four (not shown), or $24 \mathrm{~h}$ (Fig. 2 $A$ ). Neither message abundance nor the kinetics of $\mathrm{PLA}_{2}$ mRNA induction were altered, suggesting that this transcript is not superinduced or rapidly degraded. Inclusion of actinomycin $\mathrm{D}$ did abolish the rIL-1 induced gene expression (Fig. $2 B$ ), consistent with its effect on the PLA ${ }_{2}$ activity measured previously in acid extracts (9). Taken together, these data suggest that the rIL-1 stimulated PLA $_{2}$ activity requires de novo RNA synthesis that results in the coordinate synthesis and secretion of enzyme.

We next determined whether the IL-1-induced increase in $\mathrm{PLA}_{2}$ mRNA levels was in fact due to enhanced transcription, increased mRNA stability or both. Fig. $3 \mathrm{~A}$ shows a representative run-off transcription analysis which demonstrates that rIL1 increased the rate of $P_{2 A}$ mRNA transcription. In three separate experiments, analysis of $\mathrm{PLA}_{2}$ nuclear transcript abundance, corrected for background and normalized for changes in GAPDH transcripts, indicated that PLA Pranscrip- $^{2}$ tion rate increased $219 \pm 18 \%$ in cells stimulated with IL-1 for $15 \mathrm{~h}$ compared to cell incubated with vehicle. The rIL-1-stimulated increase in $\mathrm{PLA}_{2}$ transcription rate was suppressed by concentrations of $\alpha$-amanitin that specifically inhibit polymerase II activity (not shown). We also examined whether IL-1 also had an effect on PLA ${ }_{2}$ RNA turnover (Fig. $3 B$ ). In the presence of actinomycin $\mathrm{D}, \mathrm{PLA}_{2}$ mRNA degradation is exceeding slow, a finding which was unaffected by the presence of IL-1 in the incubation medium. In contrast, the half-life of tubulin transcripts in the same cells was $\sim 3 \mathrm{~h}$, a decay rate similar to that reported for this mRNA in other cell lines (20).
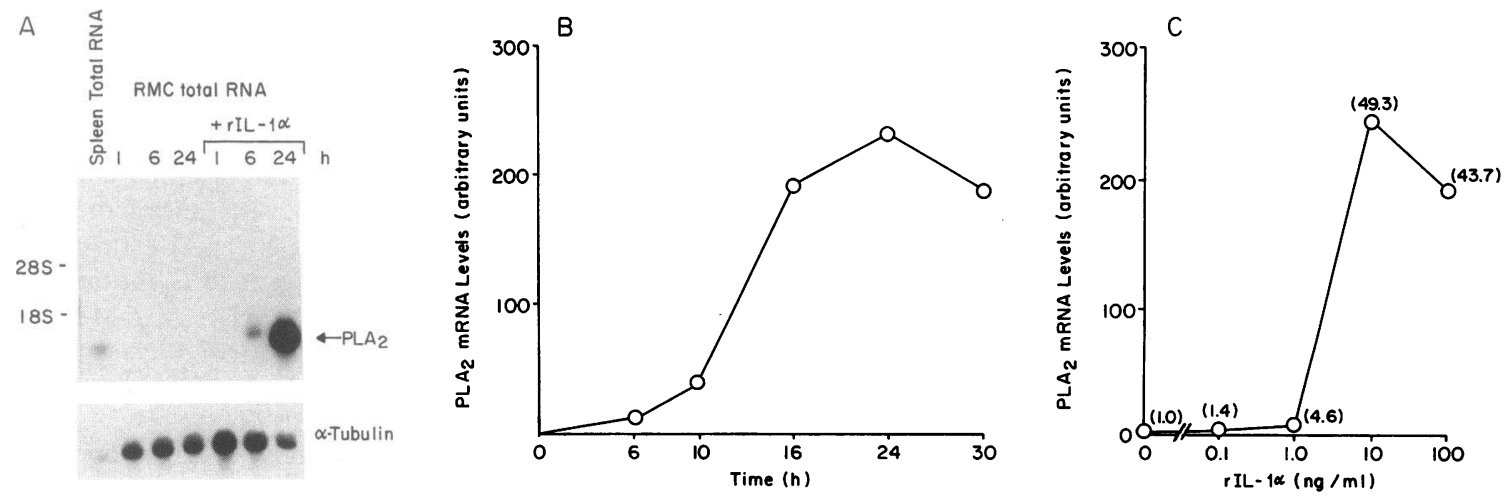

Figure 1. rIL-1 induces $\mathrm{SPLA}_{2}$ mRNA expression. Each experiment is representative of two to three replicates. $(A)$ Northern Analysis. Mesangial cells were incubated with rIL-1 $(10 \mathrm{ng} / \mathrm{ml})$ or vehicle for the indicated times. Total cellular RNA $(20 \mu \mathrm{g})$ was analyzed for PLA ${ }_{2}$ by Northern analysis as described in Methods and demonstrated a $1.0 \mathrm{~kb}$ species only in cytokine-stimulated cells. The filter was rehybridized with chicken $\alpha$-tubulin $(1.2 \mathrm{~kb})$ to demonstrate the integrity of the RNA, the equivalence of loading, and the specificity of mRNA induction. Spleen RNA was also analyzed as a positive control and demonstrates a 0.8 kb PLA 2 transcript. $(B)$ Time course for rIL-1 induced PLA $A_{2}$ expression. Mesangial

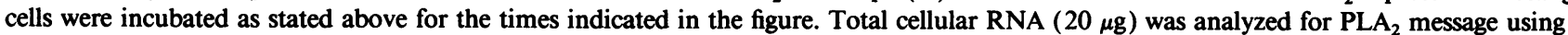
RNA-RNA solution hybridization as described in detail in Methods and in Fig. 2. Autoradiograms were quantitated by densitometry and the results presented as total peak area for each time point. $(C)$ Dose-dependence of IL-1-induced PLA $\mathrm{A}_{2}$ MNA expression. PLA $\mathrm{A}_{2}$ expression at 24 $\mathrm{h}$ was analyzed as described for graph $B$. PLA $A_{2}$ activity in the medium was measured as described in Methods and is shown in parenthesis as the relative stimulation above the control value (1.0). Actual control and rIL-1 stimulated mean PLA $\mathrm{A}_{2}$ activities are shown in Table I. 
Table I. Secreted PLA $A_{2}$ Activity in Response to the Indicated Agonists

\begin{tabular}{lc}
\hline \multicolumn{1}{c}{ Condition } & PLA $_{2}$ activity \\
\hline & nmol hydrolyzed/h \\
A. Cycling $M C$ & \\
Control & $60 \pm 10$ \\
IL- $\alpha(10 \mathrm{ng} / \mathrm{ml})$ & $1,680 \pm 260$ \\
IL- $\beta(50 \mathrm{ng} / \mathrm{ml})$ & $3,200 \pm 110$ \\
LPS $(10 \mu \mathrm{g} / \mathrm{mL})$ & $250 \pm 10$ \\
IL-2 $(1,500 \mathrm{U} / \mathrm{ml})$ & $40 \pm 10$ \\
Forskolin $(10 \mu \mathrm{M})$ & $60 \pm 10$ \\
Forskolin $+\mathrm{rlL}-1 \alpha$ & $5,210 \pm 900$ \\
Dibutyryl cAMP $(1 \mathrm{mM})$ & $50 \pm 10$ \\
Dibutyryl $+\mathrm{rIL}-1 \alpha$ & $2,280 \pm 40$ \\
DiOG $(100 \mu \mathrm{M})$ & $70 \pm 10$ \\
OAG $(50 \mu \mathrm{g} / \mathrm{ml})$ & $70 \pm 10$ \\
PA $(50 \mu \mathrm{g} / \mathrm{ml})$ & $67 \pm 10$ \\
TPA $(0.1 \mu \mathrm{M})$ & $50 \pm 10$ \\
Dexamethasone $(1 \mu \mathrm{M})$ & $50 \pm 10$ \\
Dexamethasone $+\mathrm{rIL}-1 \alpha$ & $1,340 \pm 15$ \\
B. Serum-Deprived $M C$ & \\
rIL-1 $\alpha(10 \mathrm{ng} / \mathrm{ml})$ & $220 \pm 30$ \\
PDGF $(25 \mathrm{ng} / \mathrm{ml})+\mathrm{rIL}-\alpha$ & $139 \pm 30$ \\
& \\
\hline
\end{tabular}

Mesangial cells were incubated for $24 \mathrm{~h}$ with the indicated agonist as

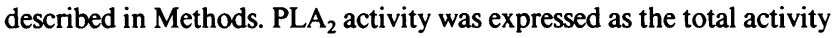
present in the media at the end of the incubation period. Results were expressed as the mean \pm SEM of 2-7 determinations.

These data demonstrate that IL-1-stimulated increases in steady state PLA ${ }_{2}$ mRNA abundance resulted from a two-tothree-fold increase in the $\mathrm{PLA}_{2}$ transcription rate that is amplified by the prolonged persistence of the transcript. Although the lack of $\mathrm{PLA}_{2}$ mRNA degradation is striking, agonist stimulated accumulation of other mRNAs have been reported to result from a similar mechanism (20).

To better define the potential role of $\mathrm{PLA}_{2}$ in immune-me- diated glomerular injury, we next examined the effect of several cytokines, which have been implicated in the pathogenesis of experimental and human glomerulonephritis, on mesangial cell PLA ${ }_{2}$ expression. The data are shown in Fig. 4. TNF, rIL$1 \alpha$, and rIL- $\beta$ markedly stimulated PLA $_{2}$ message expression. LPS was less potent while IL-2 had no effect. As indicated, enzyme activity released into the medium (Fig. 4, Table I) was coordinate with mRNA induction. In addition, neither PDGF (see below) nor epidermal growth factor (not shown) stimulated mesangial cell PLA $_{2}$ expression.

Forskolin and dibutyryl cAMP potentiate but do not mediate rIL-1-stimulated PLA 2 expression. We are interested in defining the pathways used by IL- 1 in mesangial cells to activate a change in cellular function. IL-1 induces cAMP accumulation in some cells, and $\mathrm{PLA}_{2}$ activity has been reported to be stimulated by cAMP-elevating agents in vascular smooth muscle cells (21), astrocytes (22), and rat mesangial cells (23). We therefore examined the effect of forskolin and dibutyryl cAMP on $\mathrm{PLA}_{2}$ gene expression and $\mathrm{PLA}_{2}$ activity. As shown in Fig. 5 $A$, addition of forskolin $(10 \mu \mathrm{M})$ significantly enhanced IL-1-induced PLA P $_{2}$ message expression by nearly fourfold ( $360 \pm 41 \%$ stimulation, mean \pm SEM, $n=3$ individual experiments, $P<0.02)$. Similar results were obtained for a permeable cAMP analog, dibutyryl cAMP ( $1 \mathrm{mM})$ (Fig. $5 B$ ). The amount of $\mathrm{PLA}_{2}$ activity in the medium reflected the degree of mRNA expression (Fig. 5, Table I). In contrast, neither forskolin nor dibutyryl cAMP alone induced $\mathrm{PLA}_{2}$ gene expression (Fig. 5) or release of enzyme activity (Table I). The inactive forskolin analog 1, 9-dideoxyforskolin, $(10 \mu \mathrm{M})$, butyrate $(0.2$ $\mathrm{mM})$, and dibutyryl cGMP ( $1 \mathrm{mM})$ also failed to potentiate the IL-1 response (data not shown). Taken together, these results suggest that activation of protein kinase $A$ potentiates but does not mimic IL-1-stimulated mesangial cell PLA $\mathrm{P}_{2}$ expression.

Diradylglycerols, phosphatidic acid, and phorbol ester do not mimic or alter rIL-1-induced PLA, expression. We and others have shown that several lipid signals are rapidly formed in IL-1-stimulated mesangial cells, including 1,2-diacylglycerol and phosphatidic acid $(10,11)$. As shown in Fig. $6 A$, the
A

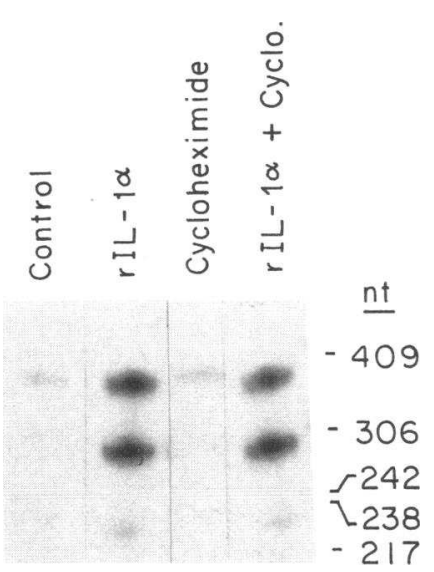

Figure 2. Effect of protein (diagram $A$ ) and RNA synthesis (diagram $B$ ) inhibitors on IL-1-stimulated PLA $\mathrm{A}_{2}$ message expression. Mesangial cells were incubated in the presence of rIL-1 $(10 \mathrm{ng} / \mathrm{ml})$ or vehicle for 24 h. Cycloheximide $(1 \mu \mathrm{g} / \mathrm{ml})$ or actinomycin $\mathrm{D}(0.2 \mu \mathrm{g} / \mathrm{ml})$ was added concurrently to some dishes with or without rIL-1. Total RNA was analyzed for $P_{L A}$ transcripts by RNA-RNA solution hybridization as described in Methods. A [ ${ }^{32} \mathrm{P}$ ] riboprobe was synthesized from a linearized DNA temnt plate that contained the cDNA sequence (bp 381-758) for rat splenic nonpancreatic (type II) PLA . This PLA $_{2}$ mRNA contains a heterologous nucleotide ( $\mathrm{nt} 461$ ) which generates the indicated protected fragments shown ( $378 \mathrm{nt}$ and $297 \mathrm{nt}$ ). Markers were $\left[{ }^{32} \mathrm{P}\right]$ labeled fragments of a MSP I digest pBR322. The figure is representative of duplicate experiments. 


\section{A Nuclear Run-offs}

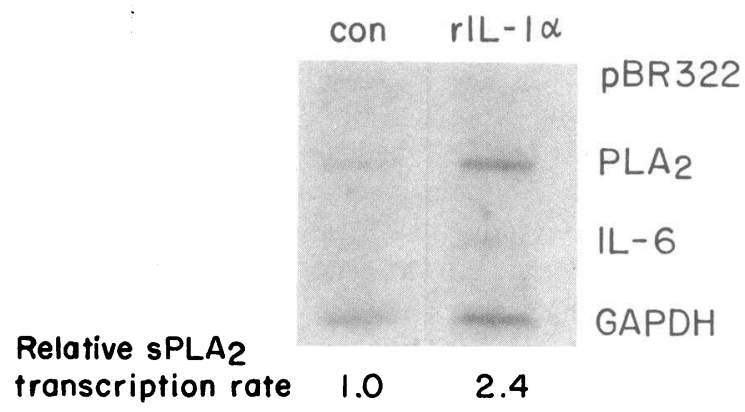

B PLA2 mRNA Stability

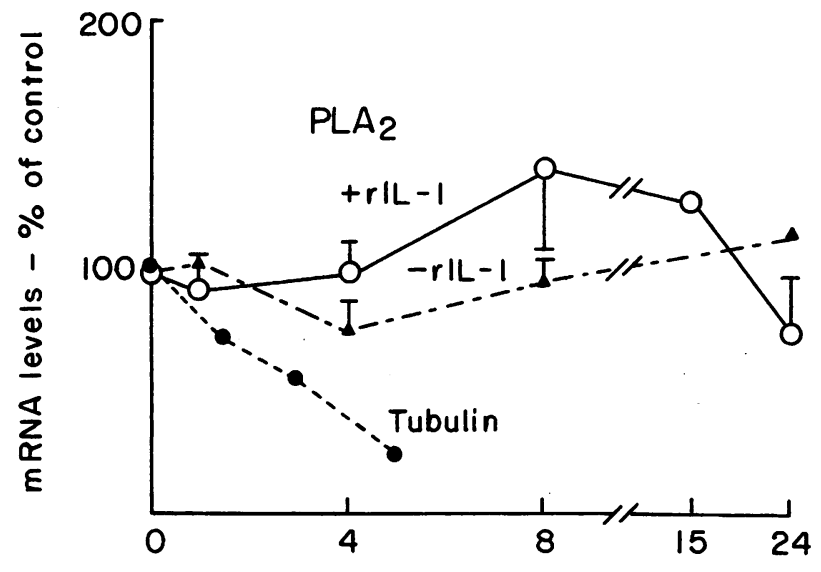

Time ( $h$ ) after addition of Actinomycin D

Figure 3. Effect of rIL-1 on PLA 2 mRNA transcription $(A)$ and stability $(B)$. $(A)$ Mesangial cells were incubated with RPMI media alone or with rIL-1 $(10 \mathrm{ng} / \mathrm{ml})$ for $15 \mathrm{~h}$. Nuclei were isolated and a run-off transcription analysis was performed as described in Methods. Densitometric scans of the nascent transcripts hybridized to each plasmid were obtained, and the PLA $\mathrm{P}_{2}$ transcription rate was quantified as described in Methods. This diagram is representative of three individual experiments. $(B)$ The effect of rIL-1 on PLA mRNA $_{2}$ turnover was assessed by Northern analysis. Mesangial cells were incubated in the presence of IL-1 $(10 \mathrm{ng} / \mathrm{ml})$ for $24 \mathrm{~h}$. Actinomycin $\mathrm{D}(5 \mu \mathrm{g} / \mathrm{ml})$ was added and the cells harvested at the indicated times (curve marked "+ IL-1"). In some experiments, IL-1 was removed and fresh media containing actinomycin $\mathrm{D}$ was added (curve marked “-IL-1"). Total cellular RNA (20 $\mu \mathrm{g})$ was analyzed for PLA mRNA $_{2}$ abundance by Northern analysis. $\alpha$-tubulin mRNA levels were determined also and a representative decay curve is shown. PLA ${ }_{2}$ and tubulin mRNA levels were quantified as described in Methods and are expressed as percent of transcript abundance prior to the addition of actinomycin D ( 0 time value). PLA $A_{2}$ mRNA levels are the mean \pm SEM for 2-5 experiments.

addition of diacylglycerol analogs, DiOG $(100 \mu \mathrm{M})$ or OAG $(50 \mu \mathrm{g} / \mathrm{ml})$, did not stimulate PLA $_{2}$ gene expression or enhance phospholipase $A_{2}$ activity in the medium (Table $I$ ). Phosphatidic acid $(50 \mu \mathrm{g} / \mathrm{ml})$ also failed to stimulate PLA expression (Fig. $6 B$ ). The protein kinase $C$ activator TPA also did not increase mesangial cell PLA ${ }_{2}$ mRNA or enzyme activity (Fig. $6 B$ and Table I) or alter rIL-1-induced PLA A $_{2}$ synthesis when it was coincubated with the cytokine (data not shown). These observations indicate that the effects of IL- 1 on the mesangial cell are not mediated or modified by the activation of protein kinase $\mathrm{C}$. Consistent with this supposition, we have also shown by two-dimensional gel electrophoresis that rIL-1 does not increase the phosphorylation state of the putative 80 $\mathrm{kD}$ substrate of protein kinase $\mathrm{C}$ (data not shown).

Serum modulates IL-1-stimulated PLA $A_{2}$ expression. Serum markedly alters mesangial cell $\mathrm{PGE}_{2}$ synthesis in response to rIL-1 (9), in part due to the action of serum on prostaglandin endoperoxide synthesis expression (24). We have now assessed the role of serum on IL-1 stimulation of $\mathrm{PLA}_{2}$ gene expression and activity. As shown in Fig. $7 \mathrm{~A}$, steady state $\mathrm{PLA}_{2}$ message levels in cells incubated with rIL-1 in the absence of serum were two-fold higher than those observed with rIL-1 in serumtreated cells $(209 \% \pm 27 \%$, mean \pm SEM, $n=3$ individual experiments, $P \leq 0.05$ ). PLA $_{2}$ activity measured in acid-extracts from serum-stimulated and serum-deprived, rIL-1-stimulated mesangial cells was concordant with mRNA expression (Fig. 7 $B)$. In cells coincubated with $5 \%$ FBS and rIL-1, PLA 2 activity was $220 \pm 38 \mathrm{fmol} / \mu \mathrm{g}$ per hr compared to rIL-1 stimulated activity in the absence of serum of $590 \pm 28 \mathrm{fmol} / \mu \mathrm{g} \mathrm{per} \mathrm{hr}$, ( mean \pm SEM). The presence or absence of serum alone in did not significantly alter $\mathrm{PLA}_{2}$ activity in acid extracts of mesangial cells. To assess whether the effect of serum on genes induced by rIL-1 was specific for PLA , $_{2}$, we also studied IL-1-stimulated IL- 6 gene expression in the presence and absence of FBS. In contrast to its inhibitory action on PLA P $_{2}$ expression, serum did not inhibit IL-6 steady state mRNA levels (data not

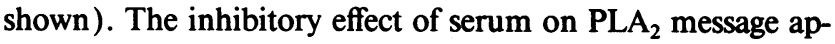
pears to be specific and not due to an alteration in IL-1 bioactivity, receptor expression or responsiveness of the cells to cytokine.

We next examined potential mechanisms by which serum could regulate IL-1-stimulated $\mathrm{PLA}_{2}$ expression. Serum contains a number of biologically active compounds, including hormones and growth factors. The synthetic glucocorticoid dexamethasone has been shown previously to inhibit PLA ${ }_{2}$ activity and the expression of other IL-1-stimulated mRNAs and proteins (25). However, coincubation of mesangial cells with rIL-1 and dexamethasone did not significantly change PLA mRNA abundance or activity when compared to cells exposed to rIL-1 alone (Fig. $8 A$ and Table I).

Several growth factors in serum activate receptor protein tyrosine kinases. The effect of the tyrosine kinase inhibitor, genistein, on cytokine-stimulated mesangial cell PLA mRNA $_{2}$ expression is shown in Fig. $8 \mathrm{~B}$. Genistein $(10 \mu \mathrm{g} / \mathrm{ml})$ markedly increased rIL-1-stimulated message accumulation in serum-stimulated RMC compared to vehicle $(444 \pm 12 \%$ stimulation, mean \pm SEM, duplicate experiments). Genistein at this concentration had no effect on cell viability as assessed by an assay of mitochondrial respiration (9). The growth factor PDGF is an abundant constituent of serum, activates a receptor tyrosine kinase, and is a potent mesangial cell mitogen and a mediator of glomerular injury. PDGF $(25 \mathrm{ng} / \mathrm{ml})$ alone did not stimulate PLA $\mathrm{A}_{2}$ mRNA synthesis or enzyme activity in serum-deprived cells but mimicked the effect of 5\% FBS on

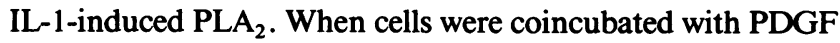
and IL-1, PLA ${ }_{2}$ transcript abundance was reduced by $72 \pm 8 \%$, (mean \pm SEM, duplicate experiments). PDGF also attenuated the IL-1-stimulated PLA $_{2}$ activity released in the media by $44 \% \pm 9$ (Table I). Taken together, these data suggest that IL-1-stimulated PLA P $_{2}$ expression can be regulated by growth factor activation of receptor tyrosine kinases. 
A

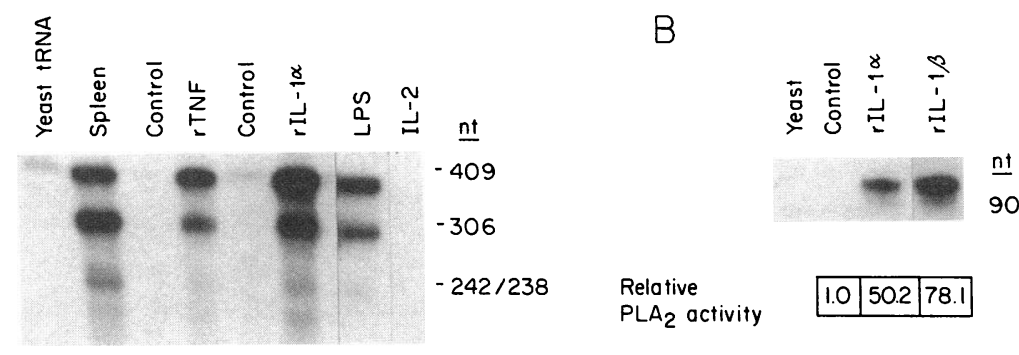

Figure 4. Effect of cytokines and LPS on $\mathrm{PLA}_{2}$ message expression and activity. Each panel is representative of at least duplicate experiments. $(A)$ Total RNA was isolated from mesangial cells incubated with TNF ( $50 \mathrm{ng} / \mathrm{ml})$, rIL-1 $\alpha(10 \mathrm{ng} / \mathrm{ml})$, rIL-1 $\beta(50 \mathrm{ng} / \mathrm{ml})$, LPS $(10 \mu \mathrm{g} / \mathrm{ml})$, or IL-2 $(1,500 \mathrm{U} / \mathrm{ml})$ for $24 \mathrm{~h}$. PLA 2 message was quantitated using RNA-RNA solution hybridization using the probe described in Fig. 2. (B) Hybridization conditions were identical to $A$, except that the $\left[{ }^{32} \mathrm{P}\right] \mathrm{cRNA}$ probe used was transcribed from a cDNA template that contained the sequence (bp

$\mathrm{PLA}_{2}$ activity

666-759) of rat spleen nonpancreatic (type II) $\mathrm{PLA}_{2}$ (see Methods). $\mathrm{PLA}_{2}$ activity released into the medium in response to the indicated stimulus was quantitated and normalized as described in Fig. 1, and is expressed under the appropriate lane in each panel. Actual PLA $\mathrm{A}_{2}$ activities for the condition in $A$ and $B$ are shown in Table $\mathrm{I}$.

\section{Discussion}

IL-1 and TNF activate mesangial cells to express new structural and functional characteristics, a process which involves specific changes in gene activity in the nucleus. We have studied regulation of a nonpancreatic (Type II) PLA $_{2}$ to understand the intracellular pathways engaged in cytokine-activated mesangial cells. PLA ${ }_{2}$ expression provides a reasonable model system for defining mechanisms of transcriptional induction by IL-1 in mesangial cells, since we have shown this gene is transcriptionally regulated by IL-1, and that it is not detectable in quiescent, serum-stimulated, or growth factor-activated cells.

The basis for the specificity in gene induction by particular polypeptide ligands is poorly understood. In this study, we have used second messenger mimics to explore the intracellular pathways used by IL-1 to stimulate gene transcription. Our data show that protein kinase $\mathrm{C}$ activation ( this paper), cAMP accumulation (this paper, reference 14), or rapid changes in cytosolic $\mathrm{Ca}^{2+}$ or $\mathrm{pH}_{\mathrm{i}}(10)$ are not required for IL-1-directed $\mathrm{PLA}_{2}$ gene expression and suggest that other signaling path- ways are engaged directly by IL-1 to induce PLA $\mathrm{P}_{2}$ mRA expression. Since $\mathrm{PLA}_{2}$ gene expression is cycloheximide insensitive, we believe these signals ultimately activate transcription factor(s) by posttranslational modifications.

Several mechanisms can be proposed to describe how IL-1IL-1-receptor interactions directly alter gene activity in the nucleus. Traditional models of transmembrane signaling propose that a limited number of second messengers convey the information generated by a ligand-receptor interaction. Using this model in conjunction with published information describing IL-1-activated transmembrane signaling pathways (2, 10-14), we would suggest that IL-1 alters the phosphorylation state of a transcriptional factor or transcription factor complex by activating a kinase cascade. IL-1 can change protein phosphorylation patterns by activating extracellular signal-related kinase/ mitogen-activated peptide kinase (ERK/MAP kinase) (26, 27 ) or by inhibiting phosphatase activity (28). Recent data suggest phosphorylation state can regulate transcriptional factor activity. Both c-jun and CREB are positively regulated by phosphorylation $(29,30)$. Translocation of the $\mathrm{rel} / \mathrm{k} \beta$ proteins

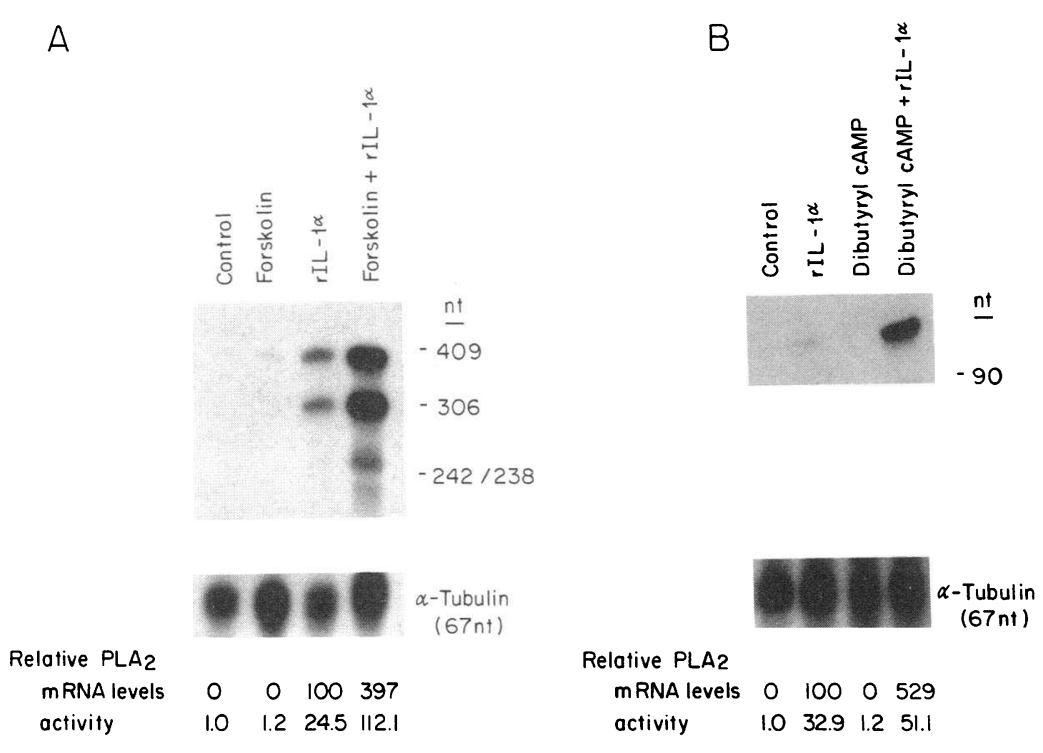

Figure 5. Forskolin $(A)$ and dibutyryl cAMP $(B)$ enhance rIL-1-stimulated PLA $_{2}$ mRNA expression. Mesangial cells were incubated for $24 \mathrm{~h}$ with forskolin $(10 \mu \mathrm{M})$ or dibutyryl cAMP $(1 \mathrm{mM})$ with or without rIL-1 $(10 \mathrm{ng} / \mathrm{ml})$. The data presented in $A$ is representative of three separate experiments and that in $B$ is representative of duplicate experiments. $(A)$ Total mRNA $(15 \mu \mathrm{g})$ was analyzed by solution hybridization for $\mathrm{PLA}_{2}$ message expression using the probe described in Fig. 2. The samples were concurrently hybridized with a [ ${ }^{32} \mathrm{P}$ ]probe for chicken $\alpha$-tubulin. The signal intensities of the protected fragments for each mRNA species were quantitated by densitometry, and the PLA $\mathrm{A}_{2}$ mRNA expression was corrected for changes in the tubulin transcript abundance. Relative mesangial cell PLA $\mathrm{P}_{2}$ mRNA expression after rIL-1-stimulation was arbitrarily defined as 100 units. Released PLA $_{2}$ activity was quantified and expressed as described in Fig. 1. (B) Total mRNA ( $15 \mu \mathrm{g})$ was analyzed for $\mathrm{PLA}_{2}$ message and quantified as described in $A$, except the [ $\left.{ }^{32} \mathrm{P}\right] \mathrm{PLA}_{2}$ probe described in Fig. $3 B$ was used. Relative PLA $A_{2}$ activity is presented as described in Fig. 1. Actual PLA 2 activities for the conditions shown in $A$ and $B$ are presented in Table I. 
A
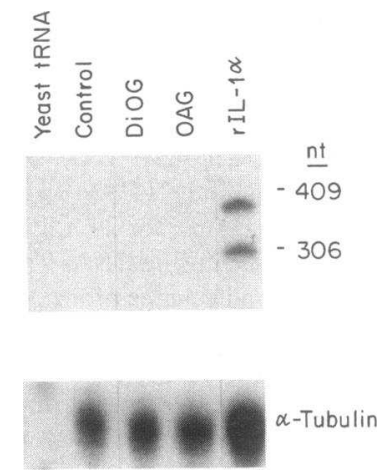

Relative

$\mathrm{PLA}_{2}$ octivity

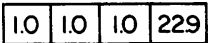

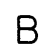
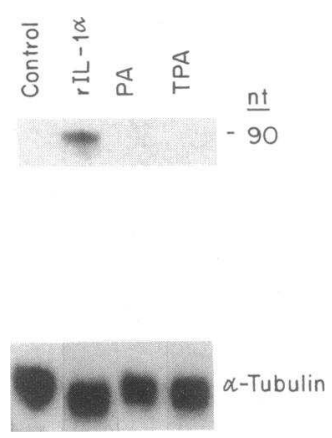

Relative
PLA2 activity 1.0 \begin{tabular}{|l|l|l|l|}
\hline & 64.5 & 1.0 & 1.0 \\
\hline
\end{tabular}
Figure 6. The effect of diradyglycerols, phorbol ester, and phosphatidic acid on mesangial cell PLA $\mathrm{A}_{2}$ mRNA expression. $(A)$ Mesangial cells were incubated for 24 $\mathrm{h}$ in medium in the presence or absence of DiOG ( 100 $\mu \mathrm{M})$, OAG $(50 \mu \mathrm{g} / \mathrm{ml})$ for $24 \mathrm{~h}$. Total RNA (15 $\mu \mathrm{g})$ was analyzed for PLA $_{2}$ message, using the probe described in Fig. 2, and tubulin mRNA. The panel is representative of two experiments. $(B)$ Mesangial cells were incubated for $24 \mathrm{~h}$ with rIL-1 $(10 \mathrm{ng} / \mathrm{ml})$, PA $(50 \mu \mathrm{g} / \mathrm{ml})$ or TPA $(0.1 \mu \mathrm{M})$ and analyzed for PLA and tubulin mRNA expression as described in $A$, except the probe described in Fig. $3 B$ was used. The figure is representative of two separate experiments. In both $A$ and $B$ relative PLA ${ }_{2}$ activity in the medium is presented as previously described in Fig. 1. Actual $\mathrm{PLA}_{2}$ activities for the conditions shown in $A$ and $B$ are in Table I. to the nucleus requires phosphorylation of associated inhibitory proteins, which tether them in the cytosol (31). In this model, specificity of gene induction by IL-1 results from unique interactions between activated transcription factors.

Recent work, which describes the pathways used by interferon- $\alpha / \beta$ to induce gene expression, suggests an alternative model (32-34). Treatment of cells with interferon immediately phosphorylates three proteins, which comprise a unique transcriptional activator that translocates to the nucleus to induce a specific gene set. These data, which suggest the existence of many ligand-specific, direct signaling pathways, would predict that binding of IL-1 to its receptor catalyzes a posttranscriptional modification of a specific, latent cytoplasmic transcription factor(s). This latter model is consistent with our data demonstrating the inability of second messenger mimics to induce PLA ${ }_{2}$ mRNA expression. However, neither IL-1-specific transcriptional proteins nor specific IL-1 responsive DNA elements have been identified.

In the context of other published studies $(21,22,35)$, our findings with second messenger molecules demonstrate that
Type II PLA $\mathrm{P}_{2}$ expression is regulated in a cell-specific manner. Raising cytosolic cAMP levels potentiates IL-1-induced PLA mRNA enzyme activity in all cell types studied $(21,22)$, but the adenylate cyclase activator forskolin in the absence of cytokine induces PLA $_{2}$ synthesis only in vascular smooth muscle cells (21). The protein kinase activator TPA stimulates astrocytes to synthesize and release $\operatorname{PLA}_{2}$ (22), but fails to increase either PLA ${ }_{2}$ mRNA abundance or enzyme activity in the mesangial cell and vascular smooth muscle cell (21). Finally, cycloheximide induces PLA $_{2}$ mRNA in smooth muscle cells, suggesting the existence of short-lived negative regulators (35), but does not superinduce PLA ${ }_{2}$ transcript expression in mesangial cells. The regulation of $\mathrm{PLA}_{2}$ synthesis appears to be complex and highly dependent on the target cell type and the stimulus employed. Cell specific expression of the gene appears to result, at least in part, from unique interactions between signaling pathways.

Other polypeptide ligands present in the glomerular microenvironment may modulate induction of $\mathrm{PLA}_{2}$ expression by IL-1. In vitro, serum negatively regulates IL-1-stimulated
A
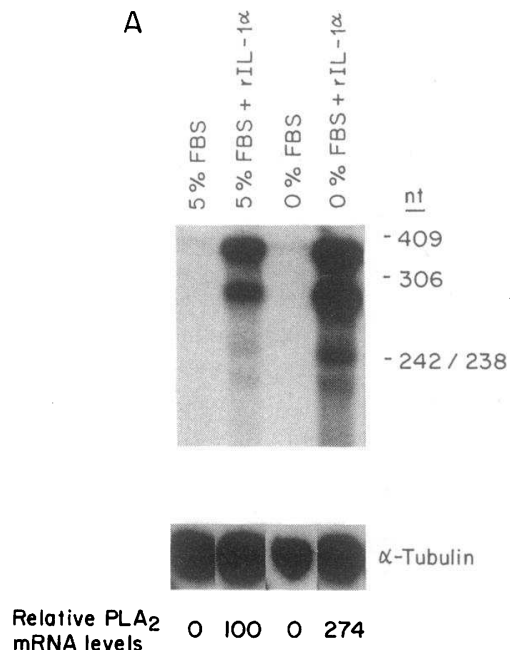

B

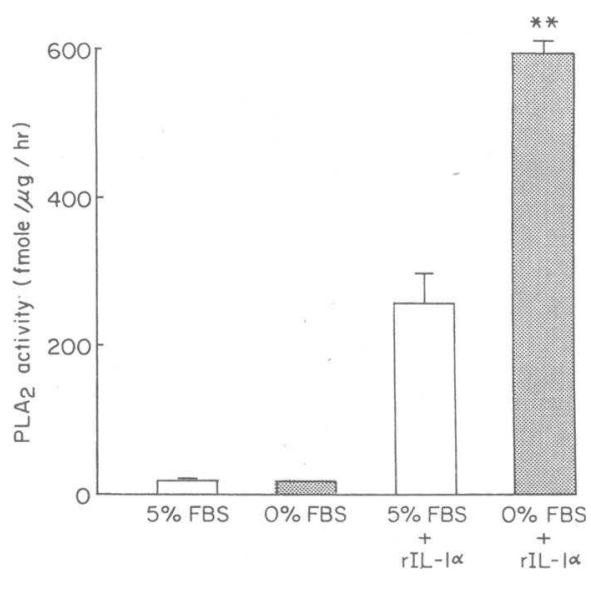

Figure 7. Suppression of rIL-1-stimulated $\mathrm{PLA}_{2}$ expression by serum. $(A)$ Mesangial cells were incubated for $24 \mathrm{~h}$ in the presence or absence of rlL-1 $(10 \mathrm{ng} / \mathrm{ml})$ in RPMI media with or without $5 \%$ FBS. Total RNA $(15 \mu \mathrm{g})$ was analyzed by RNARNA solution hybridization using the $\left[{ }^{32} \mathrm{P}\right]-$ probe described in Fig. 2. PLA 2 mRNA abundance were corrected for changes in tubulin mRNA expression as previously described in Fig. 4. The effect of rIL-1 in the presence of $5 \%$ FBS is arbitrarily defined as 100 units. This panel is representative of three separate experiments. $(B)$ $\mathrm{PLA}_{2}$ activity in acid extracts of mesangial cells. The cells were cultured for $24 \mathrm{~h}$ in the presence of rlL-1 $(10 \mathrm{ng} / \mathrm{ml})$ with or without $5 \%$ FBS. Cell homogenates were acid-extracted and assayed for PLA $\mathrm{P}_{2}$ activity as described in Methods. Data are expressed as mean \pm SEM, for $2-5$ individual experiments. ${ }^{* *} P<0.005$, compared to cells incubated with rIL-1 in the presence of $5 \% \mathrm{FBS}$. 


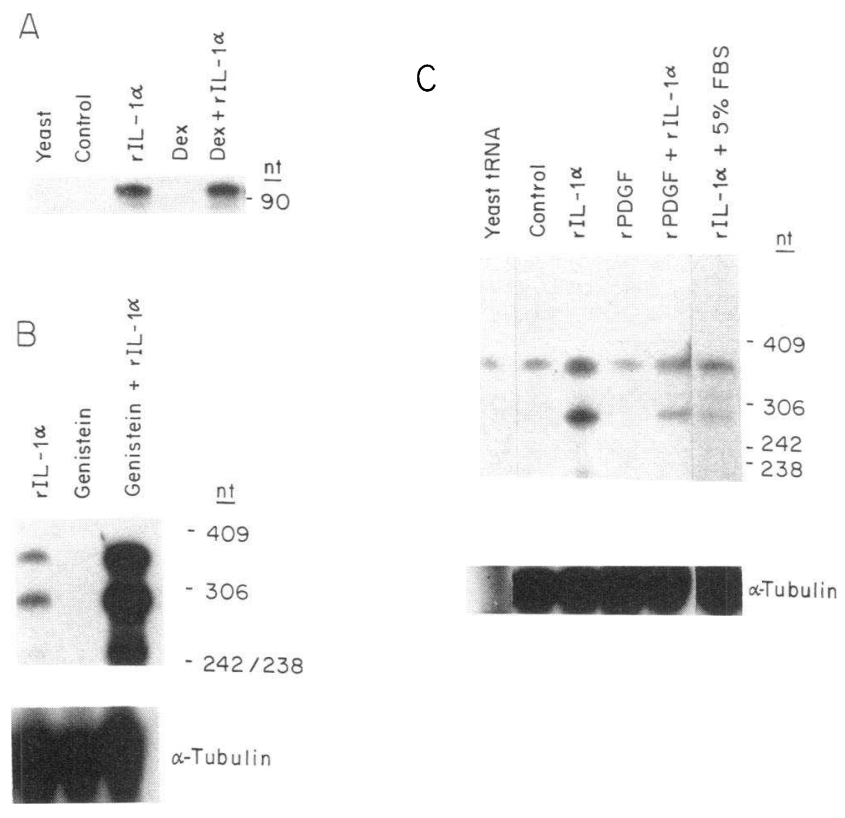

Figure 8. Regulation of rIL-1 stimulated PLA ${ }_{2}$ expression by serum components. Each panel is representative of at least two separate experiments. $(A)$ Cells were cultured for $24 \mathrm{~h}$ in the absence of serum with dexamethasone (Dex, $1 \mu \mathrm{M}$ ) or vehicle in the presence or absence of rIL-1 $(10 \mathrm{ng} / \mathrm{ml})$. Mesangial cell PLA $\mathrm{m}_{2} \mathrm{mRA}$ expression was analyzed using the probe described in Fig. $3 B$. $(B)$ Mesangial cells were incubated in $5 \% \mathrm{FBS}$, and treated with genistein $(10 \mu \mathrm{g} / \mathrm{ml})$ or vehicle $30 \mathrm{~min}$ before the addition of rIL-1 $(10 \mathrm{ng} / \mathrm{ml})$ or vehicle. Parallel studies confirmed this concentration of genestein blocked growth factor activated receptor tyrosine kinase activity. Both PDGF-stimulated tyrosine phosphorylation, as determined by immunoblotting, and mesangial cell mitogenesis, as assessed by $\left[{ }^{3} \mathrm{H}\right]-$ thymidine incorporation and cell counts, were inhibited. Cellular RNA was harvested after $24 \mathrm{~h}$ and $\mathrm{PLA}_{2}$ and tubulin message were analyzed as previously described. $(C)$ Cells were serum-restricted for $3 \mathrm{~d}$ then incubated with PDGF $(25 \mathrm{ng} / \mathrm{ml})$, $\mathrm{rIL}-1(10 \mathrm{ng} / \mathrm{ml})$, or both for $24 \mathrm{~h}$. Total RNA was isolated and analyzed for PLA $\mathrm{P}_{2}$ and tubulin message as previously described.

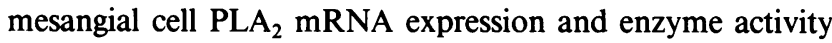
but not IL-6 mRNA expression. This specificity in the effect of serum suggests the mechanism does not involve an inhibitor of IL-1 present in FBS ( 36 ) or the down-regulation of IL-1 receptors by chronic protein kinase C activation (37). Genistein, a relatively selective inhibitor of tyrosine kinase activity at the concentration employed, however, enhances IL-1-stimulated $\mathrm{PLA}_{2}$ mRNA expression in serum-stimulated cells. Growth factor-activated receptor tyrosine kinases may mediate the effect of serum on PLA $_{2}$ mRNA abundance. Consistent with this hypothesis, coincubation of mesangial cells with PDGF and IL-1 reproduces the effect of serum on $\mathrm{PLA}_{2}$ expression. Although PDGF also stimulates protein kinase $C$ activity, neither TPA nor diacylglycerol analogues reduce IL-1-stimulated $\mathrm{PLA}_{2}$ mRNA formation. Two recent studies have reported also that PDGF reduces PLA $_{2}$ protein synthesis $(38,39)$. Our results demonstrate this inhibition occurs at the level of mRNA abundance. Growth factors such as PDGF may counter-regulate the proinflammatory actions of cytokines. PDGF inhibits cytokine-stimulated synthesis of the complement protein Factor B, and potentiates IL-1-stimulated production of metallo- proteinases in human fibroblasts through changes in mRNA abundance $(40,41)$. Secretory Group II PLA 2 promotes inflammatory injury (42). Growth factor-dependent, down-regulation of $\mathrm{PLA}_{2}$ secretion may act to limit tissue destruction and shift the local balance to favor healing and tissue repair.

Recently a high molecular weight intracellular $\mathrm{PLA}_{2}$ $\left(\mathrm{cPLA}_{2}\right)$, that is mechanistically and biochemically distinct from the Type II 14-kD PLA 2 we have studied, has been described in the mesangial cell $(42,43)$. We and others have demonstrated that within minutes IL-1 activates $\mathrm{CPLA}_{2}$ by phosphorylation $^{2}(44,45)$. However, the precise function of each isoform in arachidonate metabolism and mesangial cell function and glomerular inflammation remains to be defined. Some, but not all studies, have suggested that activation of both isoforms results in arachidonic acid hydrolysis $(42,45-47)$. The 14-kD, secreted PLA ${ }_{2}$ may be targeted to the cell membrane to hydrolyze phospholipids, an action that fails to irreversibly injure the cell $(46,47)$. A regulatory mechanism must prevent lethal cell injury to allow the low molecular weight $\mathrm{PLA}_{2} \mathrm{~s}$ to alter cell function independently of membrane disruption.

Both in vitro and in vivo studies suggest the mesangial cell expresses distinct phenotypes in response to changes in the glomerular microenvironment. Regulation of the Type II PLA gene presents a useful model for understanding how regulatory proteins and intracellular signaling pathways fit together to determine mesangial cell fate. Future work on this model system hopefully will discriminate the distinctive signaling pathways used by the mesangial cell for specialized responses to cytokines and provide insight in kidney-specific mechanisms of gene expression.

\section{Acknowledgments}

The authors thank Kathy Kashnier for excellent secretarial assistance and Drs. Carlin, Ganz, and King for their careful review of the manuscript.

This work was supported by grants from the National Institute of Diabetes, Digestive and Kidney Diseases (DK-38558) and the Community Dialysis Centers. Dr. Sedor is an Established Investigator of the American Heart Association.

\section{References}

1. Schlondorff, D. 1987. The glomerular mesangial cell: an expanding role for a specialized pericyte. FASEB (Fed. Am. Soc. Exp. Biol.) J. 1:272-281.

2. Striker, L. J., E. P. Peten, S. J. Elliot, T. Doi, and G. E. Striker. 1991. Mesangial cell turnover: effect of heparin and peptide growth factors. Lab. Invest. 64:446-456.

3. Sedor, J. R., Y. Nakazato, M. Konieczkowski. 1992. IL-1 and the mesangial cell. Kidney Int. 41:595-599.

4. Emancipator, S. N., and J. R. Sedor. 1992. Cytokines and renal disease. In Cytokines in Health and Disease: Physiology and Pathophysiology. S. L. Kunkel, and D. G. Remick, editors. Marcel Dekker, Inc., New York. 467-488.

5. Kusner, D. J., E. L. Luebbers, R. J. Nowinski, M. Konieczkowski, C. H. King, and J. R. Sedor. 1991. Cytokine- and LPS-induced synthesis of interleukin8 from human mesangial cells. Kidney Int. 39:1240-1248.

6. Zoja, C., J. M. Wang, S. Bettoni, M. Sironi, D. Renzi, F. Chiaffarino, H. E. Abboud, J. Van Damme, A. Mantovani, G. Remuzzi, and A. Rambaldi. 1991

2. Konieczkowski, M., J. H., Gronich, and J. R. Sedor. 1993. Interleukin-1 causes rapid activation of cytosolic phospholipase $A_{2}$ by phosphorylation in rat mesangial cells. Manuscript submitted for publication. 
Interleukin- $1 \beta$ and tumor necrosis factor- $\alpha$ induce gene expression and production of leukocyte chemotactic factors, colony-stimulating factors, and interleukin-6 in human mesangial cells. Am. J. Pathol. 138:991-1003.

7. Abbott, F., J. J. Ryan, M. Ceska, K. Matsushima, C. E. Sarraf, and A. J. Rees. 1991. Interleukin-1 $\beta$ stimulates human mesangial cells to synthesize and release interleukins-6 and -8. Kidney Int. 40:597-605.

8. Martin, J., D. H. Lovett, D. Gemsa, R. B. Sterzel, and M. Davies. 1986. Enhancement of glomerular mesangial cell neutral proteinase secretion by macrophages: role of interleukin 1. J. Immunol. 137:525-529.

9. Nakazato, Y., M. S. Simons, W. H. Herman, M. Konieczkowski, and J. R. Sedor. 1991. Interleukin-1 $\alpha$ stimulates prostaglandin biosynthesis in serum-activated mesangial cells by induction of a non-pancreatic (Type II) phospholipase A2. J. Biol. Chem. 266:14119-14127.

10. Kester, M., M. S. Simonson, P. Mene, and J. R. Sedor. 1989. Interleukin-1 generates transmembrane signals from phospholipids through novel pathways in cultured rat mesangial cells. J. Clin. Invest. 83:718-723.

11. Bursten, S. L., W. E. Harris, K. Bomsztyk, and D. Lovett. 1991. Interleukin-1 rapidly stimulates lysophosphatidate acyltransferase and phosphatidate phosphohydrolase activities in human mesangial cells. J. Biol. Chem. 266:20732-20743.

12. Sedlak, T. W., Y. Nakazato, and J. R. Sedor. 1991. Tumor necrosis factor $\alpha$ activates a serine, theonine protein kinase distinct from protein kinase $\mathrm{C}$ in mesangial cells. J. Am. Soc. Nephrol. 12:463 (Abstr.).

13. Pfeilschifter, J., J. Leighton, W. Pignat, F. Märki, and K. Vosbeck. 1991. Cyclic AMP mimics, but does not mediate, interleukin-1- and tumour-necrosisfactor-stimulated phospholipase $A_{2}$ secretion from rat renal mesangial cells. Biochem. J. 273:199-204.

14. Pfeilschifter, J., and H. Schwarzenbach. 1990. Interleukin 1 and tumor necrosis factor stimulate cGMP formation in rat renal mesangial cells. FEBS (Fed. Eur. Biochem. Soc.) Lett. 273:185-187.

15. Marsden, P. A., and B. J. Ballerman. 1990. Tumor necrosis factor activates soluble guanylate cyclase in bovine mesangial cells via an L-arginine-dependent mechanisms. J. Exp. Med. 172:1843-52.

16. Wiggins, R. C., N. Njoku, and J. R. Sedor. 1990. Tissue factor production by cultured rat mesangial cells. Stimulation by TNF $\alpha$ and lipopolysaccharide. Kidney Int. 37:1281-1285.

17. Werber, H. I., S. N. Emancipator, M. L. Tykocinski, and J. R. Sedor. 1987. The interleukin 1 gene is expressed by rat glomerular mesangial cells and is augmented in immune complex glomerulonephritis. J. Immunol. 138:32073212.

18. Linial, M., N. Gunderson, and M. Groudine. 1985. Enhanced transcription of c-myc in bursal lymphoma cells requires continuous protein synthesis. Science (Wash. DC). 230:1126-1132.

19. Stoeckle, M. Y. 1991. Post-transcriptional regulation of gro $\alpha, \beta$, gamma, and IL-8 mRNAs by IL-1 $\beta$. Nucleic Acids Res. 19:917-920.

20. Hargrove, J. L., and F. H. Schmidt. 1989. The role of mRNA and protein stability in gene expression. FASEB (Fed. Am. Soc. Exp. Biol.) J. 3:2360-2370.

21. Nakano, T., O. Ohara, H. Teraoka, and H. Arita. 1990. Group II phospholipase $A_{2}$ mRNA synthesis is stimulated by two distinct mechanisms in rat vascular smooth muscle cells. FEBS (Fed. Eur. Biochem. Soc.) Lett. 261:171-174.

22. Oka, S., and H. Arita. 1991. Inflammatory factors stimulate expression of group II phospholipase $\mathrm{A}_{2}$ in rat cultured astrocytes. J. Biol. Chem. 266:99569960.

23. Pfeilschifter, J., J. Leighton, W. Pignat, F. Märki, and K. Vosbeck. 1991. Cyclic AMP mimics, but does not mediate, interleukin-1- and tumour-necrosisfactor-stimulated phospholipase $\mathrm{A}_{2}$ secretion from rat renal mesangial cells. Biochem. J. 273:199-204.

24. Simonson, M. S., J. A. Wolfe, M. Konieczkowski, J. R. Sedor, and M. J. Dunn. 1991. Regulation of prostaglandin endoperoxide synthase gene expression in cultured rat mesangial cells: induction by serum via a protein kinase-c-dependent mechanisms. Mol. Endocrinol. 5:441-451.

25. Mukaida, N., C. C. O. Zachariae, G. L. Gusella, and K. Matsushima. 1991. Dexamethasone inhibits the induction of monocyte chemotactic-activating factor production by IL-1 or tumor necrosis factor. J. Immunol. 146:1212-1215.

26. Guy, G. R., S. P. Chua, N. S. Wong, S. B. Ng, and Y. H. Tan. 1991. Interleukin 1 and tumor necrosis factor activate common multiple protein kinases in human fibroblasts. J. Biol. Chem. 266:14343-14352.
27. Bird, T. A., P. R. Sleath, P. C. deRoos, S. K. Dower, and G. D. Virca. 1991. Interleukin-1 represents a new modality for the activation of extracellular signal-regulated kinases/microtubule-associate protein-2 kinases. J. Biol. Chem. 266:22661-22670.

28. Guy, G. R., S. Cao, S. P. Chua, and Y. H. Tan. 1992. Okadaic acid mimics multiple changes in early protein phosphorylation and gene expression induced by tumor necrosis factor or interleukin-1. J. Biol. Chem. 267:1846-1852.

29. Smeal, T., Binetruy, B., Mercola, D. A., Birrer, M., and Karin, M. 1991. Oncogenic and transcriptional cooperation with Ha-Ras requires phosphorylation of c-Jun on serines 63 and 73. Nature (Lond.). 354:494-496.

30. Gonzalez, G. A., and Montminy, M. R. 1989. Cyclic AMP stimulates somatostatin gene transcription by phosphorylation of CREB at serine 133. Cell. 59:565-680.

31. Link, E., Kerr, L. D., Schreck, R., Zabel, U., Verma, I., and Baeuerle, P. A. 1992. Purified IкB- $\beta$ is inactivated upon dephosphorylation. J. Biol. Chem. 267:239-246.

32. David, M., and A. C. Larner. 1992. Activation of transcription factors by interferon-alpha in a cell-free system. Science (Wash. DC). 257:813-815.

33. Velazquez, L., M. Fellous, G. R. Stark, and S. Pellegrini. 1992. A protein tyrosine kinase in the interferon $\alpha / \beta$ signaling pathway. Cell. 70:313-322.

34. Schindler, C., K. Shuai, V. R. Prezioso, and J. E. Darnell, Jr. 1992. Interferon-dependent tyrosine phosphorylation of a latent cytoplasmic transcription factor. Science (Wash. DC). 257:809-813.

35. Ohara, O., J. Ishizaki, T. Nakano, H. Arita, and H. Teraoka. 1990. A simple and sensitive method for determining transcription initiating site: identification of two transcription initiation sites in rat group II phospholipase $\mathbf{A}_{2}$ gene. Nucleic Acids Res. 18:6997-7002.

36. McKenzie, R. C., C. B. Harley, S. Jatic, and D. N. Sauder. 1990. Fetal bovine serum contains an inhibitor of interleukin-1. J. Immunol. Methods. 133:99-105.

37. Horuk, R., and J. L. Gross. 1990. Protein kinase C-linked inactivation of the interleukin-1 receptor in a human transformed B-cell line. Biochem. Biophys. Acta. 1052:173-178.

38. Muhl, H., T. Geiger, W. Pignat, F. Märki, H. van den Bosch, N. Cerletti, D. Cox, G. McMaster, K. Vosbeck, and J. Pfeilschifter. 1992. Transforming growth factors type- $\beta$ and dexamethasone attenuate group II phospholipase $A_{2}$ gene expression by interleukin-1 and forskolin in rat mesangial cells. FEBS (Fed. Eur. Biochem. Soc.) Lett. 301:190-194.

39. Schalkwijk, C., J. Pfeilschifter, F. Mărki, and H. van den Bosch. 1992. Interleukin-1 $\beta$ - and forskolin-induced synthesis and secretion of group II phospholipase $A_{2}$ and prostaglandin $E_{2}$ in rat mesangial cells is prevented by transforming growth factor- $\beta 2$. J. Biol. Chem. 267:8846-8851.

40. Circolo, A., G. F. Pierce, Y. Katz, and R. C. Strunk. 1990. Antiinflammatory effects of polypeptide growth factors. J. Biol. Chem. 265:5066-5071.

41. Circolo, A., Welgus, H. G., Pierce, G. F., Kramer, J., and Strunk, R. C. 1991. Differential regulation of the expression of proteinases/antiporteinases in fibroblasts. J. Biol. Chem. 266:12283-12288.

42. Mayer, R. J., and L. A. Marshall. 1993. New insights on mammalian phospholipase $\mathrm{A}_{2}(\mathrm{~s})$; comparison of arachidonoyl-selective and -nonselective enzymes. FASEB (Fed. Am. Soc. Exp. Biol.) J. 7:339-348.

43. Gronich, J. H., J. V. Bonventre, and R. A. Nemenoff. 1988. Identification and characterization of a hormonally regulated form of phospholipase $A_{2}$ in rat renal mesangial cells. J. Biol. Chem. 263:16645-16651.

44. Sedor, J. R., M. Konieczkowski, S. Huang, J. H. Gronich, Y. Nakazato, G. Gordon, and C. H. King. 1993. Cytokines, mesangial cell activation and glomerular injury. Kidney Int. 43:S65-S70.

45. Lin, L. L., A. Y. Lin, and D. L. DeWitt. 1992. Interleukin- $1 \alpha$ induces the accumulation of cytosolic phospholipase $A_{2}$ and the release of prostaglandin $E_{2}$ in human fibroblasts. J. Biol. Chem. 267:23451-23454.

46. Murakami, M., I. Kudo, and K. Inoue. 1993. Molecular nature of phospholipases $A_{2}$ involved in prostaglandin $I_{2}$ synthesis in human umbilical vein endothelial cell. J. Biol. Chem. 268:839-844.

47. Tohkin, M., J. Kishino, J. Ishizaki, and H. Arita. 1993. Pancreatic-type phospholipase $\mathrm{A}_{2}$ stimulates prostaglandin synthesis in mouse osteoblastic cells (MC3T3-E1) via a specific binding site. J. Biol. Chem. 268:2865-2871. 